\title{
Aerobic and Anaerobic Sewage Biodegradable Processes: The Gap Analysis
}

\author{
Anijiofor Sandra C. ${ }^{1,2}$, Nor Azreen Mohd Jamil ${ }^{3,4}$, Sarah Jabbar ${ }^{1}$, Saad Sakyat ${ }^{1}$ \\ Chandima Gomes ${ }^{3 *}$ \\ ${ }^{1}$ Department of Civil Engineering, Universiti Putra Malaysia, 43400 Serdang, Selangor, Malaysia \\ ${ }^{2}$ Department of Civil Engineering, Federal Polytechnic, PMB 1034, BirninKebbi, Kebbi State, Nigeria. \\ ${ }^{3}$ Department of Electrical and Electronics Engineering, Universiti Putra Malaysia, 43400 Serdang, Selangor, \\ Malaysia. \\ ${ }^{4}$ Department of Plant Biotechnology, Agro-Biotechnology Institute, National Institute of Biotechnology \\ Malaysia, 43400 Serdang, Selangor, Malaysia
}

*Corresponding Author: Chandima Gomes, ${ }^{3}$ Department of Electrical and Electronics Engineering, Universiti Putra Malaysia, 43400 Serdang, Selangor, Malaysia. E-mail: chandima.gomes@gmail.com

\begin{abstract}
Wastewaterhas become a significant risk and danger to both physical environment and human/animal life due to inefficient management processes. There are many technologies applied in wastewater management. Among them biological treatment methods are widely used as they are cost effective, highly efficient, simple in application, less in chemical usage,less energy consuming and environment friendly.This review covers many aspects of biological wastewater treatment through aerobic and anaerobic methods with special attention on study on Upflow Anaerobic Sludge Blanket (UASB), the Expanded Granular Sludge Blanket (EGSB) and Upflow Anaerobic Sludge Blanket-aerobic digester (UASBaerobic digester). We provide a comprehensive account onthe literature on aerobic and anaerobic systems of sewage treatment with UASB, EGSB and UASB-aerobic digester reactors, a comparative analysis on the treatment efficiency of each method, outlining the merits, demerits and constraints.An appraisal tothe combination of aerobic and anaerobic systems, specifically the UASB-Aerobic digester has also been given.
\end{abstract}

Keywords: Sewage; Aerobic; Anaerobic; Aerobic-anaerobic system; UASB-AS;

\section{INTRODUCTION}

Most under-developed and developing nations are facing gross problems in sanitation, health care and spread of diseases as a result of inefficient collection and treatment of wastewater, coupled with poor health facilities and lack of shelter. Ineffective management practices of wastewater have become a significant environmental risk which consequently endangersthe environment and life. Wastewater contains high levels of biodegradable pollutants such as Total Suspended Solids (TSS), Biochemical Oxygen Demand $\left(\mathrm{BOD}_{5}\right)$ and Chemical Oxygen Demand (COD) [1]. Organic and inorganic substances resulting from domestic, agricultural and industrial wastewater is responsible for most of the water pollution problems upon release into the environment without pre-treatment. In some areas especially, thoseencountering water shortage, reuse of wastewater is crucial for conservation of water resources [2]. Treatment of wastewater, specifically, from household sewage plays a key role in urban sanitation. These treatment techniques could be divided into three categories; physical, chemical and biological methods (Table 1). Although physical and chemical treatment techniques have exclusively been used in many parts of the world, a significant number of studies have emphasized that biological method is the better alternative in most cases due to its cost-effectiveness and high efficiency. As there are not many in-depth reviews have not been done in this case during the last many years, and also such reviews make a considerable impact on the new development and future trends in the field, this study has been conducted. 
Table 1.Wastewater treatment with specific measurement parameter

\begin{tabular}{|l|l|}
\hline Wastewater treatment method & Parameters \\
\hline Physical & $\begin{array}{l}\text { Total solid (TS), total suspended solid (TSS), pH, turbidity, } \\
\text { conductivity }\end{array}$ \\
\hline Chemical & $\begin{array}{l}\text { Chemical demand } \\
\text { biological oxygen demand (BOD), total nitrogen (TN), total } \\
\text { phosphorus (TP), heavy metals }\end{array}$ \\
\hline Microbiological & Coliform \\
\hline
\end{tabular}

\section{Biological Wastewater TREATMENT}

Biological wastewater treatment occurs naturally in lakes, streams, and rivers through metabolic purification which enables the degradation of organic contaminants. Wastewater with biodegradable constituents at $0.5 \mathrm{BOD} / \mathrm{COD}$ ratio are easily treated by biological techniques such as Rotating Biological Contactors (RBC), Membrane Bio Reactors (MBR), Moving Bed Biofilm Reactor (MBBR), Upflow Anaerobic Sludge Blanket (UASB), Aerated Bio Filter (ABF), Sequencing Batch Reactors (SBR) and many others. These methods are sometimes employed as aerobic or anaerobic treatment or combination of them. Selection of the treatment process depends on various factors which include stabilization degree of the wastewater compliance to theenvironmental requirement, wastewater composition and economic viability [1]. However, there are several restrictions on this conventional biological wastewater treatment such as long hydraulic retention time (HRT), large space consumption and less ability to capture biogas. Development of more advanced high rate bioreactors will be crucial to address some problems such as obtaining ahigher yield of methane (biogas) and shorter HRT [3]. It is of interest to explore the technological and scientific gaps in wastewater treatment methods by biological techniques under aerobic and anaerobic conditions with aspecific study on the UASB, EGSB and UASB-aerobic digester systems (Figure 1).

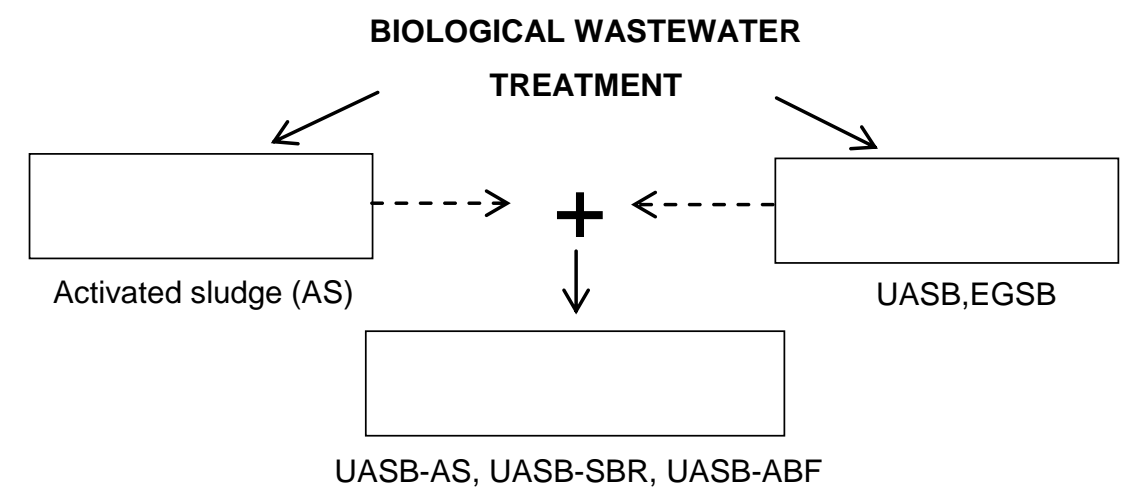

Figure 1:Wastewater treatment by biological methods

\section{Sewage Treatment}

Sewage is mainly generated from domestic or household wastes, industrial wastes and rain water[4]. The sewage characteristics are different based on factors such as theamount of daily use of water, quality of water supply, type and number of industrial activity in thenearby area, conditions of sewerage systems, public behavior and habits, soil types, landfill material etc. Domestic sewage consists of about $99.9 \%$ water and $0.1 \%$ solids, either organic or inorganic, and exhibit soapy and cloudy appearance which turns darker and produces distinct odour with time as the sewage decays due to microbial activity [1]. Typical characteristics of domestic sewage are shown in Table 2.

The concentrations of contaminants vary in different areas depending on the housing types, commercial and industrial activities nearby. High BOD/COD loading is generally applied for low income and informal areas. Heavy metals and other toxic compounds like, chromium, zinc, copper etc. are found in domestic sewage due to the discharge of industrial and animal wastes. In Palestine and Jordan, the COD content of domestic sewage is more than $1500 \mathrm{mg} / \mathrm{L}$ with $70 \%$ to $80 \%$ of suspended solids [5]. Due to different characteristics of wastewater, different methods, therefore, have been employed in wastewater treatment. Treatment of domestic sewage by well-designed and operated systems is able to remove asignificant amount of pollutants. Various methods; either through physical, chemical or biological; have been applied for sewage treatment to achieve environmental compliance wastewater level. 
Table 2.Characteristics of domestic sewage

\begin{tabular}{|lc|}
\hline Parameters & Range $\mathrm{mg} / \mathrm{L}$ \\
\hline Total suspended solids (TSS) & $250-400$ \\
Total dissolved solids (TDS) & $250-850$ \\
Total solids (TS) & $350-1200$ \\
Biochemical Oxygen Demand (BOD) & $100-300$ \\
Total Nitrogen (TN) & $20-85$ \\
Total phosphorus (TP) & $6-25$ \\
Fats & $100-200$ \\
Chlorides & $30-100$ \\
Alkalinity & $50-200$ \\
Faecal coliforms & $2-3010 \% / 100 \mathrm{ml}$ \\
Chromium & $0.1-0.5$ \\
Copper & $0.2-0.5$ \\
Lead & $0.08-0.4$ \\
Zinc & $0.4-0.7$ \\
Adapted from FAO Corporate Document Repository; Wastewater Characteristics and Effluent Quality \\
Parameters
\end{tabular}

\section{Biological Waste Water Treatment: Aerobic Versus Anaerobic}

Aerobic biodegradation involves a process that converts oxygen to water by microorganisms in order to transform organic components into more simple end products [1]. Thermophilic aerobic is used for the treatment of high strength and high-temperature wastewater which offers rapid rates of biodegradation, low sludge production as anaerobic treatment process and very good stability as compared to mesophilic process. High strength wastewater contains enough energy for auto-thermal process and therefore no exogenous heat is required. The thermophilic aerobic technique has been used in wastewater treatment from livestock's, industry and other wastewater sources [6-8]. Anaerobic treatment on the other hand, is used to treat high concentration of biodegradable contaminants in wastewater such as domestic sewage, animal manure slurry, and wastes from biosolids and food processing. This process is known as the primary method for protecting the environment and preservation of resources because it provides a sustainable wastewater treatment when combined with another appropriate system[9, 10]. The process stabilizes water with little production of biomass. Anaerobic process can be divided into hydrolysis (an enzyme-mediated conversion of complex organic compounds into simple product such as amino acids and sugars), acidogenesis (conversion of the simple products into simple organic acids such as acetic acid and propionic acid) and methanogenesis (conversion of the organic acids into biogas (methane and carbon dioxide). Hydrolytic microorganisms use ahydrolytic enzyme to create a suitable environment for acid forming bacteria. The acid formers are microorganisms that involved in acidogenesis and produce various acids while microorganisms involved in methanogenesis are known as methane formers as they convert acids into methane [11]. The methane is burned to produce heat and electricity that aids in thedigestion process of anaerobic treatment. This is very useful due to increased cost for production, treatment, and burning of fossil fuels $[3,11]$. Though conventional aerobic and anaerobic techniques have been applied previously in most wastewater treatment, high rate anaerobic bioreactor systems have been used recently to treat wastewater with high COD level $[8,10,12]$.

The natural conditions of each aerobic and anaerobic however have provided specific characteristics either suitable or not in the wastewater treatment process. Several advantages and disadvantages of applying aerobic and anaerobic methods in wastewater treatment can be viewed in term of oxygen and energy demands, removal efficiency, sludge production, operational and maintenance cost, effluent quality, space and chemical requirements, odour, nutrient removal, startup time, flexibility, clogging and microorganism concentration. The aerobic biological system is very useful for low strength wastewater treatment with COD less than $1000 \mathrm{mg} / \mathrm{L}$ and when the treatment process requires the presence of oxygen. As compared to ananaerobic system, theaerobic system also produces highquality effluent because of higher removal of soluble organic material and produces wellflocculatedbiomass which resulted in lower effluent concentration. Low-quality effluent is generated by theanaerobic system because of thelow growth rate of microorganisms, low settling rate and instabilities that lead to toxic effluent made up of ammonium ion $\left(\mathrm{NH}_{4}{ }^{+}\right)$and hydrogen sulphide (HS ). The influent produced by theaerobic system does not faceodour related problem as there is no production of biogas as in anaerobic system especially hydrogen sulphide which causes a bad smell. 
The aerobic system also does not require post treatment of wastewater as it provides better nutrient removal, while pathogens and nutrients are partly removed in theanaerobic system as the treatment time is limited; hence a post treatment is required. However, there are also several disadvantages of aerobic biological waste water treatment. The presence of oxygen during aerobic treatment has increased the tendency of formation of refractory organic compounds from biodegradable compounds. Low load and uncontrolled growth of biofilm of theaerobic system may lead to clogging and cause blockage of air circulation as a result of thethick growth of the biofilm which will start to foul and degrade. Anaerobic biological treatment provides more advantages as compared to aerobic system. The anaerobic system produces very low sludge that is de-waterable and fully stabilized for disposal. Besides, anaerobic system is cheaper, simple and flexible as compared to aerobic system which is high investment, operational and maintenance costs, labour intensive, complex infrastructure and high space requirement. Other advantages of anaerobic system are low consumption of energy, low nutrients and chemicals needed, great removal of contaminants especially for high COD (> $4000 \mathrm{mg} / \mathrm{L}$ ) even at low and high loading rates and production of energy gases such as methane (figure 2 ) and no clogging experiences [3, 9, 13, 14].In most cases, the anaerobic system is applied during pretreatment of high-strength organic sludge as this method is more economical and is well known as the primary source for effective wastewater management. Prior to discharge, the effluent from theanaerobic reactor will undergo post-treatment process under theaerobic condition to fulfill wastewater standard discharge requirement $[15,16]$.
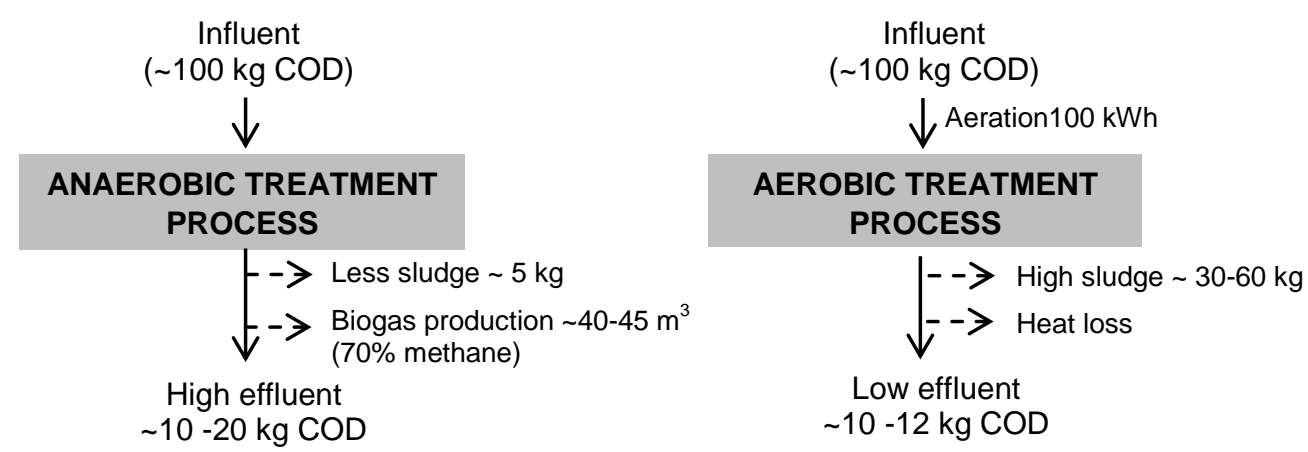

Figure 2:Sludge and biogas production in aerobic and anaerobic digestion methods

\section{UPFLOW ANAEROBIC SLUDGE BLANKET (UASB)}

The demand on anaerobic systems as the main biological step to treat wastewater becomes higher with the development of the upflow anaerobic sludge blanket (UASB) in early 1980 [4, 5, 17]. UASB reactor is a high rate anaerobic system that widely used in tropical countries which the sewage temperature is about $24^{\circ} \mathrm{C}$ to $27^{\circ} \mathrm{C}$ [4]. As reported in many studies, this system was successfully removed high COD from wastewater in warm climate countries $[14,18,19]$.It consists of thesimple solid-liquid-gas separator (GSL separator); the most important part of the system at upflow velocities of 1 to 2 meter per hour (figure 3). The separator connects the well-mixed feature of reactor contact system to separate the gas, liquid and solid phases through mechanisms of an internal gas separation and clarification. Granulation and formation of well-settable microbes occurred as the separated components pass through a bed of biomass at the bottom part of the reactor to treat wastewater either diluted or concentrated, including organic load at $40 \mathrm{~kg} / \mathrm{m}^{3}$ per day [13]. The system is popularly applied in tropical countries with thetemperature at $20^{\circ} \mathrm{C}$ to $30^{\circ} \mathrm{C}$ and at low to medium sewage strength $[13,20]$. This technology has been reported to be sustainable for treating domestic sewage in developing countries as well as in small communities [14]. However, fluctuation in temperature during winter and summer has caused changes to the sewage temperature which influenced the sludge quantity. The increment of sludge has reduced the sludge retention time (SRT) that limits the methanogens growth which resulted to poor biodegradable of suspended solids [4]. The sludge increment also reduced COD removal rate that deteriorated the sludge stability [21, 22]. Several alternatives were suggested to improve the degradation of suspended solids.This has led to the development of a novel technology such as two-stage anaerobic processes and chemically assisted sedimentation that consists of an integrated high loaded UASB reactor and a digester [18, 19, 23]. 


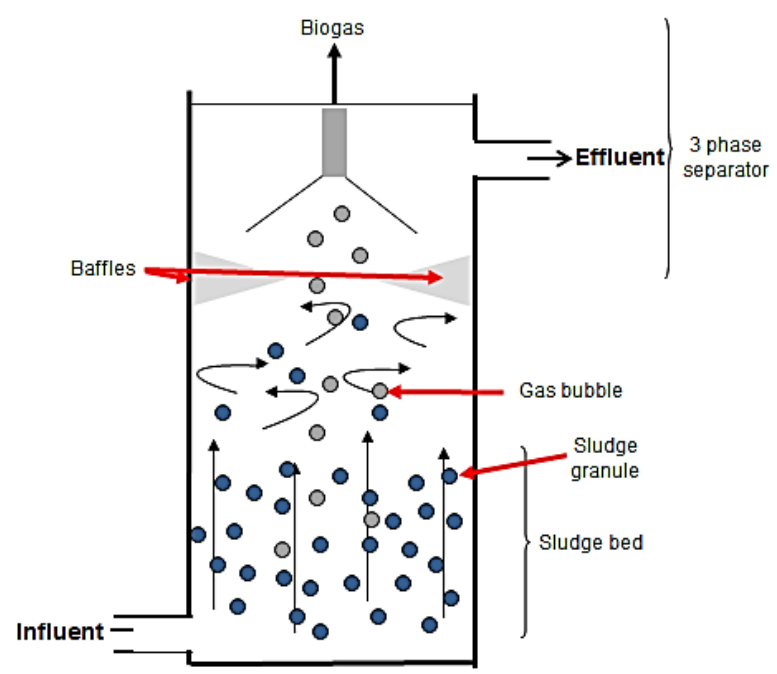

Figure 3:Concept of upflow anaerobic sludge blanket (UASB) reactor

UASB-anaerobic digester is able to stabilize the entrapped sludge in the sludge bed, followed by improvement of its methanogenic capacity $[21,24]$. The concept of UASB-anaerobic digester as the two-stage anaerobic process was involve the entrapment of and hydrolysis of organic matter into soluble compounds in the first stage; followed by digestion in the second stage. This technique was claimed has resulted in high removal efficiency as compared to single anaerobic (UASB) system [23]. A study on the system that operated at $15^{\circ} \mathrm{C}$ of UASB and $35^{\circ} \mathrm{C}$ of digester with 6 hour HRT on sewage at low temperature $\left(15^{\circ} \mathrm{C}\right)$ has shown higher efficiencies of COD removal compared to a single UASB reactor with removal of $66 \%$ and $44 \%$ total COD (CODtot), $87 \%$ and $73 \%$ suspended COD (CODsus), $44 \%$ and $3 \%$ colloidal COD (CODcol) and 30\% and 5\% dissolved COD (CODdis) for UASB-Digester and single UASB respectively. The UASB-Digester system showed $0.47 \mathrm{~g}$ sludge stability per gram COD and 47\% methanogenesis while single UASB showed $0.36 \mathrm{~g}$ sludge stability per gram COD and 20\% methanogenesis. This demonstrated that UASB-Digester has successfully reduced some weaknesses of conventional wastewater treatment system by producing low, stable and de-waterable sludge[25, 26]. Another alternative was through the use of thechemical-biological technique. Chemical was used to assist sedimentation of suspended materials in raw domestic wastewater prior to anaerobic (UASB) reactor [23]. A set up by Aiyuk et al. [27] in domestic sewage treatment was involved both pre and post treatment processes through a combination of chemicalbiological technique. The sewage was pre-treated with $50 \mathrm{mg} / \mathrm{L}$ ferric chloride $\left(\mathrm{FeCl}_{3}\right)$ and $10 \mathrm{mg} / \mathrm{L}$ polyelectrolyte prior to the treatment by UASB reactor. The sedimentation of the domestic sewage has eliminated most of the existing pathogen including $92 \%$ fecal coliform. The process was successfully removed $88 \%$ phosphate, $85 \%$ TSS and $73 \%$ total COD. However, various studies have shown that internal mixing in a UASB reactor was not optimal to treat sewage at low temperature $\left(4^{0} \mathrm{C}\right.$ to $\left.20^{\circ} \mathrm{C}\right)$ as it caused dead space inside the reactor thus reducing the efficiency of the treatment process $[28$, 29]. Later, an upgraded version of UASB system or known as expanded granular sludge blanket (EGSB) system was developed.

\section{EXPANDED GRANUlar SLUDGE BED (EGSB)}

Many efforts have been made to improve the existing wastewater treatment system including the use of various devices of feed inlet, more points of feed inlet in every square meter of thereactor and use higher velocities of superficial. For this reason, a system that able to cater most of the UASB problems has been developed. A modified version of UASB reactor known as Expanded Granular Sludge Blanket (EGSB) reactor was developed with an improvement in the characteristic of higher upflow velocity to allow better mixing at low loading rates [30]. A better distribution of influent is required to improve contact between sludge and wastewater and to consume the entire volume of reactor efficiently. The EGSB is a modification of UASB which consists of thetaller reactor (Figure 4) of high upflow velocity $(6-15 \mathrm{~m} / \mathrm{h})$ that combines with recirculation of effluent [13]. This expanded granular sludge bed (EGSB) reactor has demonstrated characteristics of better flow rate, shorter HRT and free occurrence of thedead zone. The granular sludge in EGSB reactor was able to improve liquid upflow velocity (Vup) up to 10 meters per hour compared to $0.5-1.5$ metersper hour only in UASB reactor. The high kinetic energy of effluent led to intensive organic matter-sludge contact. In contrast 
to UASB, EGSB demonstrated more refined separator, high adaptation to low temperature and wastewater strength, higher cost and ahigher tendency of washing out particulates from the sludge bed. EGSB is mainly used to treat wastewater with low strength (less than $1 \mathrm{~g} / \mathrm{L}$ COD) and low temperature $\left(10^{\circ} \mathrm{C}\right)$ since the cost is higher than UASB reactor [13]. About $70 \%$ COD and $83 \%$ TSS removal efficiencies have been achieved when EGSB reactor was used as a post-treatment of an upflow hydrolytic reactor-treated sewage of temperature above $15^{\circ} \mathrm{C}$. The removal efficiencies were reduced to $51 \%$ and $76 \%$ for COD and TSS respectively at $12^{\circ} \mathrm{C}$ with HRT of $5 \mathrm{~h}$ [31]. Other improved characteristics of EGSB as compared to UASB are including active and settle-ability of granular sludge, expanded sludge bed, higher rates of organic loading (up to $40 \mathrm{~kg} / \mathrm{m}^{3}$ ), highly applicable to more diluted wastewater when effluent recirculation is not applied, higher gas production and upflow velocity and higher chances of getting greater hydrostatic pressure on the sludge at the bottom of the reactor [9]. Later, the more innovative technology involving a combination of an integrated high-loaded UASB reactor and digester was proposed to be applicable in treating wastewater at low temperature [5].

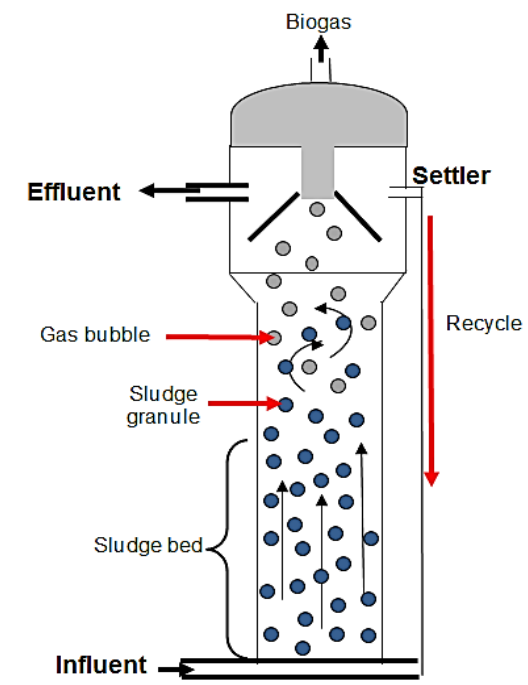

Figure 4:Concept of expanded granular sludge blanket (EGSB) reactor

\section{ANAEROBIC-AEROBIC COMBINATION SYSTEM (UASB-AEROBIC DIGESTER)}

Selection of the right combination of treatment methods is essential for effective wastewater treatment. In recent years, emphasize has been made on the ability of the high rate bioreactors to overcome challenges of space, odour, aesthetics and excess bio-solids production. Even anaerobic biological treatment system such as UASB is capable to overcome the disadvantages of the aerobic system as it uses low energy and generate low excess sludge, unfortunately, the resulted effluent from UASB reactor is unable to meet the existing discharge standards. The integrated bioreactors that combine both aerobic and anaerobic methods as a single reactor are regarded as a possible substitute which will enhance overall pollutant removal efficiency of wastewaters as well as be cost effective. Different combination methods consisting of aerobic and anaerobic reactors have been used to treat different forms of wastewaters including industrial, domestic, livestock and even wastewaters from slaughter houses [3]. Some of these combined aerobic and anaerobic treatment methods include simultaneous aerobic-anaerobic bioreactor systems (SAA), anaerobic-aerobic fixed film bioreactor (FFB), anaerobic rotating biological contactors (RBC), aerobic sequential batch reactor (SBR), upflow anaerobic sludge blanket-Continuous stirred tank reactor (UASB-CSTR), UASB-aerobic fluidized bed system (UASB-AFB), expanded granular sludge bed-aerobic biofilm reactor (EGSB$A B R$ ), anaerobic upflow bed filter-aerobic membrane bioreactor (AUBF-MBR), redial anaerobicaerobic immobilized biomass (RAAIB), UASB-SBR, UASB-RBC and UASB-activated sludge (UASB-AS).Upflow anaerobic sludge blanket-activated sludge (UASB-AS) system is one of the popular alternative techniques used in domestic wastewater treatment (figure 5). Activated sludge process has been the method of interest as it provides various advantages including high efficiency, operational flexibility, and nutrient removal. Application of UASB reactor with AS system is able to produce less sludge and consume less energy than conventional AS system [32]. Up to 60\% sludge reduction and $40 \%$ energy consumption have been shown through the use of UASB-AS system on low strength domestic wastewater $\left(340 \mathrm{mg} / \mathrm{L} \mathrm{BOD}_{5}\right)$ [20]. A study was done by Motta etal. [33] on 
UASB-AS system that circulated extra activated sludge for digestion has shown the removal efficiency of $87 \%$ and $92 \%$ of total COD and TSS respectively.

Another anaerobic-aerobic waste water treatment system that has been developed was a combination of UASB with SBR unit. This combined system has shown higher COD removal efficiency as compared to the single unit of UASB reactor in the treatment of sewage at $15^{\circ} \mathrm{C}$ [25]. A study on the use of UASB-SBR to treat domestic sewage with average COD of $587 \mathrm{mg} / \mathrm{L}$ at $25^{\circ} \mathrm{C}$ has resulted to the circulation of excess SBR sludge to the UASB reactor (Guimaraes et al., 2003). The aid of SBRs excess sludge circulation has led to the increment of OLR by $0.7 \%$ which resulted in CODtot removal rate of $95 \%$ compared to $91 \%$ CODtot removal rate by UASB reactor alone under low temperatures between $15^{\circ} \mathrm{C}$ and $30^{\circ} \mathrm{C}$ [34]. Another study on UASB-SBR system was conducted by Guimaraes et al. [35] which used $10 \mathrm{~L}$ UASB reactor and $7 \mathrm{~L} \mathrm{SBR}$ reactor to treat domestic sewage with an average COD of $587 \mathrm{mg} / \mathrm{L}$ and anaverage temperature of $25^{\circ} \mathrm{C}$. The UASB reactor was operated at $4 \mathrm{~h} \mathrm{HRT}$, with a loading rate of $3.8 \mathrm{~kg} \mathrm{COD} / \mathrm{m}^{3} /$ day and up flow velocity of $0.3 \mathrm{~m} / \mathrm{h}$; while the SBR was operated at $1 \mathrm{~h}$ aeration time and $0.5 \mathrm{~h}$ settling time. The total COD and TSS removal rates were $92 \%$ and $98 \%$ respectively as compared to the single UASB with only $82 \%$ and $83 \%$ total COD and TSS removal efficiency. This was also showed by Torres and Foresti[36] whereapproximately $91 \%$ Total COD and $84 \%$ TSS removal efficiencies were achieved by 150L UASB-90L SBR reactors on the treatment of domestic sewage with COD and TSS concentrations of $570 \mathrm{mg} / \mathrm{L}$ and $131 \mathrm{mg} / \mathrm{L}$ respectively at $21^{\circ} \mathrm{C}$ for $6 \mathrm{~h}$ HRT with a loading rate of $2.1 \mathrm{~kg} \mathrm{COD} / \mathrm{m}^{3} /$ day.

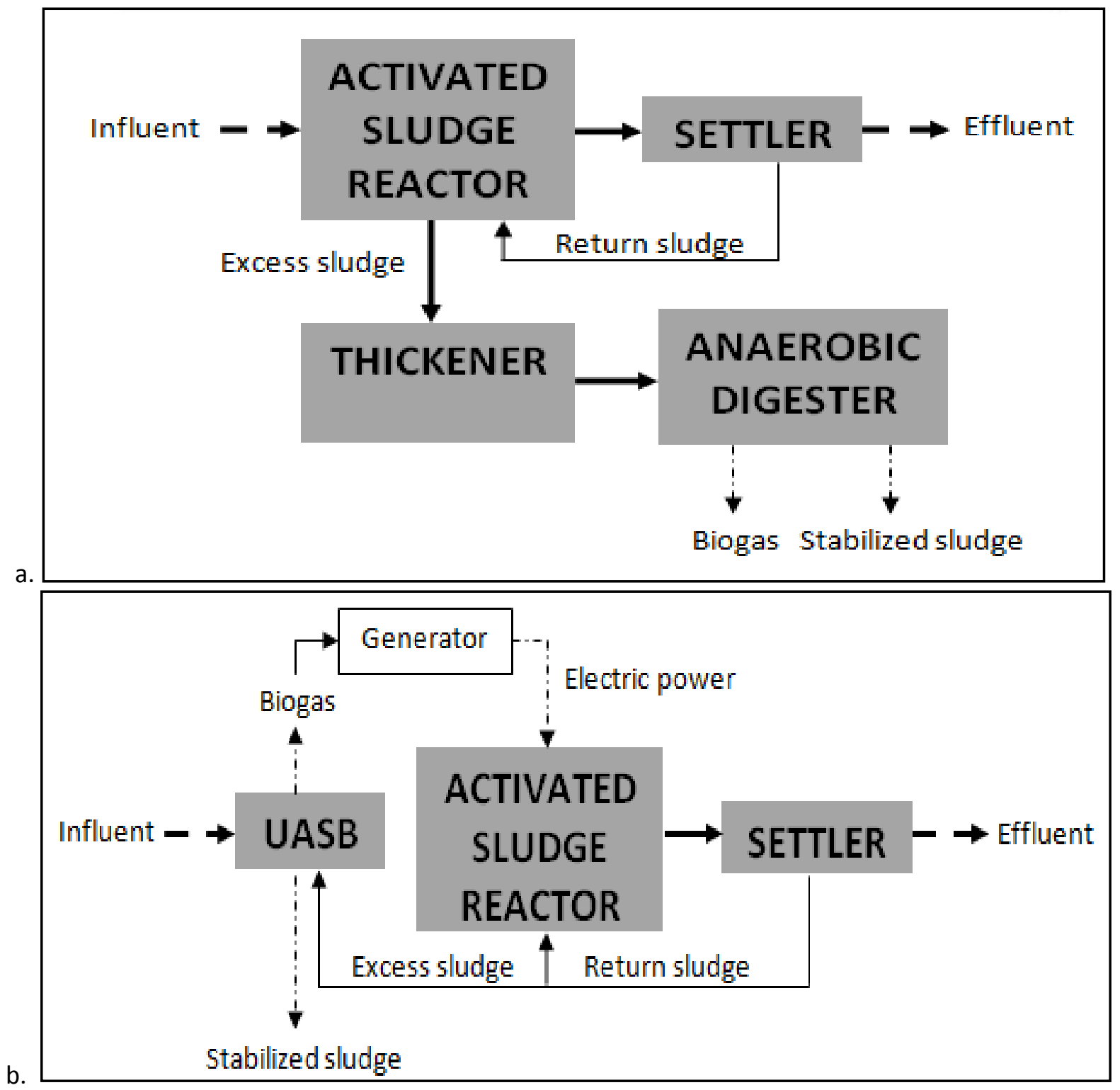

Figure 5:Concept of (a) conventional activated sludge $(A S)$ and $(b)$ upflow anaerobic sludge blanket-activated sludge (UASB-AS) 
A study on the application of a combination of UASB reactor and upflow packed bed reactor (aerobic system) or so called as aerated bio-filter (UASB-ABF) to treat domestic wastewater at $20^{\circ} \mathrm{C}$ has shownhigh quality of effluent with alow concentration of organic matter and suspended solid [29, 37]. Table 3 clearly distinguished the treatment efficiencies associated with the use of a combined aerobic and anaerobic biological treatment system for wastewaters. It was clearly seen that the removal efficiency was higher with the combined treatment system than the single treatment system. In this regard, anaerobic-aerobic treatment plants have received high attention for many years as they provide further less energy and chemical consumption, produces less sludge, uses less number of equipment, has great potential in resource recovery and very simple in operation. All the efforts were done in order to cater such drawbacks in biological wastewater techniques to attain maximum discharge standards $[38,39]$.

\section{Merits OF ANAEROBIC-AEROBIC COMBINATION SYSTEM}

The advantages associated with the anaerobic processes are outweighing the advantages of aerobic processes especially for highly concentrated influent as the anaerobic process is highly efficient in the reduction of pollutants from the wastewaters. However, complete stabilization of the organic matter from high organic strength wastewater cannot be achieved anaerobically. Therefore, theeffluent of soluble organic matter produced from the anaerobic system is suitable to be treated by aerobic technique. This shows the requirement of anaerobic-aerobic combination systems as each system is complementary to the other. A lot of benefits can be obtained with the use of the combined aerobicanaerobic treatment processes. These include: i) A great potential for energy recovery as the pretreatment of wastewater by anaerobic system is able to eliminate most of the organic contaminants and converting them into biogas; ii) High overall treatment efficiency is achieved with a total reduction of fluctuations through the post-treatment of anaerobic effluents by aerobic system; iii) Less disposal of sludge as the excess aerobic sludge is stabilized by the anaerobic tank; iv) Low consumption of energy as anaerobic pre-treatment reduces the oxygen demand of wastewater treatment in the influent equalization tank that helps to reduce required aeration capacity and; v) reduce volatilization of volatile organics during degradation by anaerobic treatment $[3,39,40]$.

Table 3:Treatment efficiencies of aerobic and anaerobic biodegradable processes on domestic sewage

\begin{tabular}{|l|c|c|c|c|c|c|}
\hline Reactor & Temp & \multirow{2}{*}{$\begin{array}{c}\text { HRT } \\
\text { type }\end{array}$} & \multicolumn{2}{|c|}{ Removal efficiency $(\%)$} & \multirow{2}{*}{ Study } \\
\cline { 4 - 6 } & $\left({ }^{0} \mathrm{C}\right)$ & $(\mathrm{h})$ & COD & TSS & BOD & {$[41]$} \\
\hline UASB & - & 6 & 63 & - & 53 & {$[9]$} \\
\hline UASB & 21 & 6 & 69 & - & 80 & {$[31]$} \\
\hline EGSB & $>15$ & 5 & 70 & 83 & - & {$[32]$} \\
\hline UASB-AS & Tropical & 4 & $85-93$ & $85-95$ & - & {$[33]$} \\
\hline UASB-AS & $15-30$ & 3.2 & 87 & 92 & - & {$[36]$} \\
\hline UASB-SBR & 21 & 6 & 91 & 84 & - & {$[35]$} \\
\hline UASB-SBR & 25 & 4 & 92 & - & 98 & \\
\hline
\end{tabular}

\section{CONCLUSION}

The combined aerobic-anaerobic systems are more effective in the treatment of domestic sewage. Application of high rate bioreactors such as UASB-AS as a combined aerobic-anaerobic system has bridged some of the gaps in wastewater treatment such as improving organic matter removal at ashorter hydraulic retention time (HRT), improving energy and chemical consumption and biogas production, and also reduction of sludge production. However, there is still a need for more improved and improvised methods of integrated systems consisting of combined aerobic and anaerobic digestion that will further bridge the distinction between the two processes.

\section{ACKNOWLEDGEMENT}

The authors would like to express high appreciation to Department of Civil Engineering, Federal Polytechnic, Nigeria and Agro-Biotechnology Institute, National Institute of Biotechnology, Malaysia for the support given during this study.

\section{REFERENCES}

[1] Tchobanoglous G, Burton F L and Stensel H D (2003) Wastewater engineering: An overview. In: Metcalf \& Eddy Inc (ed.) Wastewater Engineering, Treatment and Reuse, 4th edn. McGrawHill, New York. 24 pp. 
[2] Azizi S, Valipour A and Sithebe T (2013) Evaluation of different wastewater treatment processes and development of a modified attached growth bioreactor as a decentralized approach for small communities. The Scientific World Journal 2013 1-17.

[3] Chan Y J, Chong M F, Law C L and Hassell DG (2009) A review on anaerobic-aerobic treatment of industrial and municipal wastewater. Chemical Engineering Journal 15 (1-2) 1-18.

[4] Van Haandel A C and Lettinga G (1994) Anaerobic Sewage Treatment: A Practical Guide for Regions with a Hot Climate. John Wiley and Sons, England.

[5] Mahmoud N, Amarneh M N, Al-Sa'ed R, Zeeman G, Gijzen H and Lettinga G (2003) Sewage characterisation as a tool for the application of anaerobic treatment in Palestine. Environmental Pollution 126 (1) 115-122.

[6] Lapara T M and Alleman J E (1999) Thermophilic aerobic biological wastewater treatment. Water Research 33 (4) 895-908.

[7] J. Suvilampi and J. Rintala (2003) Thermophilic aerobic wastewater treatment, process performance, biomass characteristics, and effluent quality, Reviews in Environmental Science and Biotechnology, Volume 2, Issue 1, pp 35-51

[8] S. Nájera, M. Gil-Martínez and J. Rico-Azagra, (2017) Dual-Control of Autothermal Thermophilic Aerobic Digestion Using Aeration and Solid Retention Time, Water, 9, 426; doi:10.3390/w9060426

[9] L. Seghezzo, G. Zeeman, J. B. van Lier, H. V. M. Hamelers and G. Lettinga (1998) A review: The anaerobic treatment of sewage in UASB and EGSB reactors. BioresourTechnol 65 (3) 175190.

[10] L. Fleck, M. H. F. Tavares, E. Eyng, M. A. de M. de Andrade, and L. M. Frare (2017) Optimization of anaerobic treatment of cassava processing wastewater, Eng. Agríc. 37, 3.

[11] M. Tabatabaei, A. Sulaiman, A. M. Nikbakh, N.Yusof and G. Najafpour (2011) Influential parameters on biomethane generation in anaerobic wastewater treatment plants. In: Manzanera M (ed.) Alternative Fuel. In-Tech, Rijeka, Croatia.

[12] F. Pan, X. Zhong, D. Xia, X. Yin, F. Li, D. Zhao, H. Ji and W. Liu (2017) Nanoscale zero-valent iron/persulfate enhanced upflow anaerobic sludge blanket reactor for dye removal: Insight into microbial metabolism and microbial community, Scientific Reports, 7, Article number: 44626

[13] Aiyuk S E, Forrez I, De Lieven K, Van Haandel A and Verstraete W (2006) Anaerobic and complementary treatment of domestic sewage in regions with hot climates- A review. BioresourTechnol 97 2225-2241.

[14] Khan A A, Gaur R Z, Tyagi V K, Khursheed A, Lew B, Mehrotra I and Kazmi AA (2011) Sustainable options of post treatment of UASB effluent treating sewage: A review. Resources, Conservation and Recycling 55 (12) 1232-1251.

[15] Gasparikova E, Kapusta S, Bodík I, Derco J and Kratochvil K (2005) Evaluation of anaerobicaerobic wastewater treatment plant operations. Polish Journal of Environmental Studies 14 (1) 29-34.

[16] C. Fang, S. O-Thong.and.K. Boe, I. Angelidaki (2011) Comparison of UASB and EGSB reactors performance, for treatment of raw and deoiled palm oil mill effluent (POME), Journal of Hazardous Materials, 189, 1-2, 229-234.

[17] Lettinga G, Van Velsen A F M, Hobma S W, De Zeeuw W and Klapwijk A (1980) Use of the upflow sludge blanket (USB) reactor concept for biological wastewater treatment especially for anaerobic treatment. Biotechnology and Bioengineering 22 (4) 699-734.

[18] Oakley, S., von Sperling, M., Verbyla, M. (2017) Anaerobic Sludge Blanket Reactors. In: J.B. Rose and B. Jiménez-Cisneros, (eds) Global Water Pathogens Project. Part 4 Management of Risk from Excreta and Wastewater), Michigan State University, July 2017

[19] Antwi P, Li J, Shi E, Boadi PO, Ayivi F (2017) Modelling Biogas Fermentation from Anaerobic Digestion: Potato Starch Processing Wastewater Treated within an Up flow Anaerobic Sludge Blanket, J BioremediatBiodegrad, 8: 388.

[20] Chernicharo C A L (2005) Anaerobic reactors. In: von Sperling M and Chernicharo CAL (eds.) Biological Wastewater Treatment In Warm Climate Regions. IWA Publishing, Alliance House, London. 659-827. 
[21] Lettinga G and Hulshoff P L W (1991) UASB process design for various types of wastewater. Water Sci Technol24 (8) 87-107.

[22] Zeeman G, Sanders W T M, Wang K Y and Lettinga G (1997) Anaerobic treatment of complex wastewater and waste activated sludge-Application of an upflow anaerobic solid removal (UASR) reactor for the removal and pre-hydrolysis of suspended COD. Water Sci Technol 35 (10) 121-128.

[23] Foresti E, Zaiat M and Vallero M (2006) Anaerobic processes as the core technology for sustainable domestic wastewater treatment: Consolidated applications, new trends, perspectives and challenges. Reviews in Environmental Science and Biotechnology 5 (1) 3-19.

[24] A.B. Saner, A.K. Mungray and N.J. Mistry, (2016) Treatment of distillery wastewater in an upflow anaerobic sludge blanket (UASB) reactor, Desalination and Water Treatment, 57, 10, 4328-4344,

[25] Mahmoud N, Zeeman G, Gijzen H and Lettinga G (2004) Anaerobic sewage treatment in a one stage UASB reactor and a combined UASB digester system. Water Research 38 (9) 2347-2357.

[26] H. Jakub, D. Petr, K. Vojtech, P. Andrea, W. Patria, and B. Jan. (2016) Anaerobic Treatment of Wastewater in Colder Climates Using UASB Reactor and Anaerobic Membrane Bioreactor, Environmental Engineering Science, November 33(11): 918-928.

[27] Aiyuk S E, Amoako J, Raskin L, Van Haandel A and Verstraete W (2004) Removal of carbon and nutrients from domestic sewage using a low-cost, integrated treatment concept. Water Research 38 (13) 3031-3042.

[28] De M. Awa, Grin P C, Roersma R E, Grolle K C F and Lettinga G (1986) Anaerobic treatment of municipal wastewater at low temperatures anaerobic treatment: A grown-up technology. In: Proceeding of EWPCA Water Treatment Conference, Amsterdam, The Netherlands. 451-466.

[29] Enitan, A. M. (2015) Anaerobic digestion model to enhance treatment of brewery wastewater for biogas production using UASB reactor, Environmental Modeling and Assessment, 20: 673-685.

[30] Li X M, Guo L, Yang Q, Zeng G M and Liao D X (2007) Removal of carbon and nutrients from low strength domestic wastewater by expanded granular sludge bed-zeolite bed filtration (EGSBZBF) integrated treatment concept. Process Biochemistry 42 (8) 1173-1179.

[31] Kato M T, Florencio L and Arante R F M (2003) Post treatment of UASB effluent in an expanded granular bed reactor type using flocculent sludge. Water Sci Technol 48 (6) 279-284.

[32] Von Sperling M, Freire V H and Chernicharo C A L (2001) Performance evaluation of a UASBactivated sludge system treating municipal wastewater. Water Sci Technol 43 (11) 323-328.

[33] Motta E J, Silva E, Bustillos A, Padron H and Luque J (2007) Combined anaerobic/aerobic secondary municipal wastewater treatment: pilot-plant demonstration of the UASB/aerobic solids contact system. Journal of Environmental Engineering 133 (4) 397-403.

[34] Sousa J T and Foresti E (1996) Domestic sewage treatment in an upflow anaerobic sludge blanket-sequencing batch reactor systemWater Sci Technol 33 (3) 73-84.

[35] Guimaraes P, Melo H, Cavalcanti P and Van Haandel A (2003) Anaerobic-aerobic sewage treatment using combination UASB-SBR activated sludge. J Environ Sci Health A Tox Hazard Subst Environ Eng 38 (11) 2633-2641.

[36] Torres P and Foresti E (2001) Domestic sewage treatment in a pilot system composed of UASB and SBR reactors. Water Sci Technol 44 (4) 247-253.

[37] Jun H B, Park S M, Park J K and Lee S H (2005) Equalization characteristics of an upflow sludge blanket-aerated biofilter (USB-AF) system. Water Sci Technol 51 (10) 301-310.

[38] Semblante G, Hai F I, Ngo Hh, Guo W, You S J, Price We and Nghiem L D (2014) Sludge cycling between aerobic, anoxic and anaerobic regimes to reduce sludge production during wastewater treatment: performance, mechanisms, and implicationsBioresourTechnol 155 395409.

[39] L. Zhang (2016) Anaerobic Treatment of Municipal Wastewater in a UASB-Digester System, $\mathrm{PhD}$ thesis, Wageningen University, Wageningen, NL.

[40] S. J. Kulkarni and N. L. Shinde (2016) A review on anaerobic treatment for wastewater: Application, Method and results, International Journal of Engineering Sciences \& Management Research, 3(2.), 33-37. 
[41] Tandukar M, Ohashi A and Harada H (2007) Performance comparison of a pilot-scale UASB and DHS system and activated sludge process for the treatment of municipal wastewater, Water Research 41 (12) 2697-2705.

Citation: Anijiofor Sandra C. et al., "Aerobic and Anaerobic Sewage Biodegradable Processes: The Gap Analysis", International Journal of Research in Environmental Science, vol. 3, no. 3, p. 11, 2017. http://dx.doi.org/10.20431/2454-9444.0303002

Copyright: () 2017 Authors. This is an open-access article distributed under the terms of the Creative Commons Attribution License, which permits unrestricted use, distribution, and reproduction in any medium, provided the original author and source are credited. 